\title{
When Indian crabs were not yet Asian - biogeographic evidence for Eocene proximity of India and Southeast Asia
}

\author{
Sebastian Klaus $^{1 *}$, Christoph D Schubart ${ }^{2}$, Bruno Streit ${ }^{1}$, Markus Pfenninger ${ }^{1,3}$
}

\begin{abstract}
Background: The faunal and floral relationship of northward-drifting India with its neighboring continents is of general biogeographic interest as an important driver of regional biodiversity. However, direct biogeographic connectivity of India and Southeast Asia during the Cenozoic remains largely unexplored. We investigate timing, direction and mechanisms of faunal exchange between India and Southeast Asia, based on a molecular phylogeny, molecular clock-derived time estimates and biogeographic reconstructions of the Asian freshwater crab family Gecarcinucidae.

Results: Although the Gecarcinucidae are not an element of an ancient Gondwana fauna, their subfamily Gecarcinucinae, and probably also the Liotelphusinae, evolved on the Indian Subcontinent and subsequently dispersed to Southeast Asia. Estimated by a model testing approach, this dispersal event took place during the Middle Eocene, and thus before the final collision of India and the Tibet-part of Eurasia.

Conclusions: We postulate that the India and Southeast Asia were close enough for exchange of freshwater organisms during the Middle Eocene, before the final Indian-Eurasian collision. Our data support geological models that assume the Indian plate having tracked along Southeast Asia during its move northwards.
\end{abstract}

\section{Background}

The Indian Subcontinent has a biogeographic key position between Africa, Madagascar and Eurasia. It has been involved in faunal exchange between the continents during the Late Cretaceous and Paleogene by either serving as a biotic ferry for a Gondwana fauna [1-4], or as a target [5-7], stepping-stone [8,9] or source $[8,10]$ for dispersal. For all biogeographic scenarios involving the Indian Subcontinent, the assumed geological setting is of major importance; especially the time of fragmentation of Eastern Gondwana, the position of Greater India on its move northwards relative to the adjacent continents, and the timing of the IndianEurasian collision.

The standard geological view dates the IndianEurasian collision to the Paleocene/Early Eocene at 50$55 \mathrm{Ma}$ [11-13]. However, there is stringent evidence

\footnotetext{
* Correspondence: klaus@bio.uni-frankfurt.de

'Department of Ecology and Evolution, Goethe University, Frankfurt am Main, Germany

Full list of author information is available at the end of the article
}

from both geological data and plate modeling approaches for a much later collision around $35 \mathrm{Ma}$, preceded by collision with an intraoceanic island arc around $55 \mathrm{Ma}$ [14-17]. Ali and Aitchison [17] presented two hypotheses on the location of India during its Eocene northward movement. The first is based on the motion path of the Indian Subcontinent according to Schettino and Scotese [18] and assumes India in an isolated position until final contact with Tibet (Fig. 1B). The second hypothesis, using the motion path of Acton [19], reconstructs India in close proximity to Southeast Asia from Eocene to Oligocene, possibly tracking along Sumatra, the Malay Peninsula and Burma, and allowing terrestrial connections (Fig. 1A). Depending on which of the two geological models fits better to the actual Indian motion path, one should expect different biogeographic and phylogenetic patterns as both models allow different spatial and temporal dispersal pathways. In particular, the geological history should be reflected by taxa with limited marine dispersal capabilities, e.g., terrestrial nonvolant or limnic organisms. 


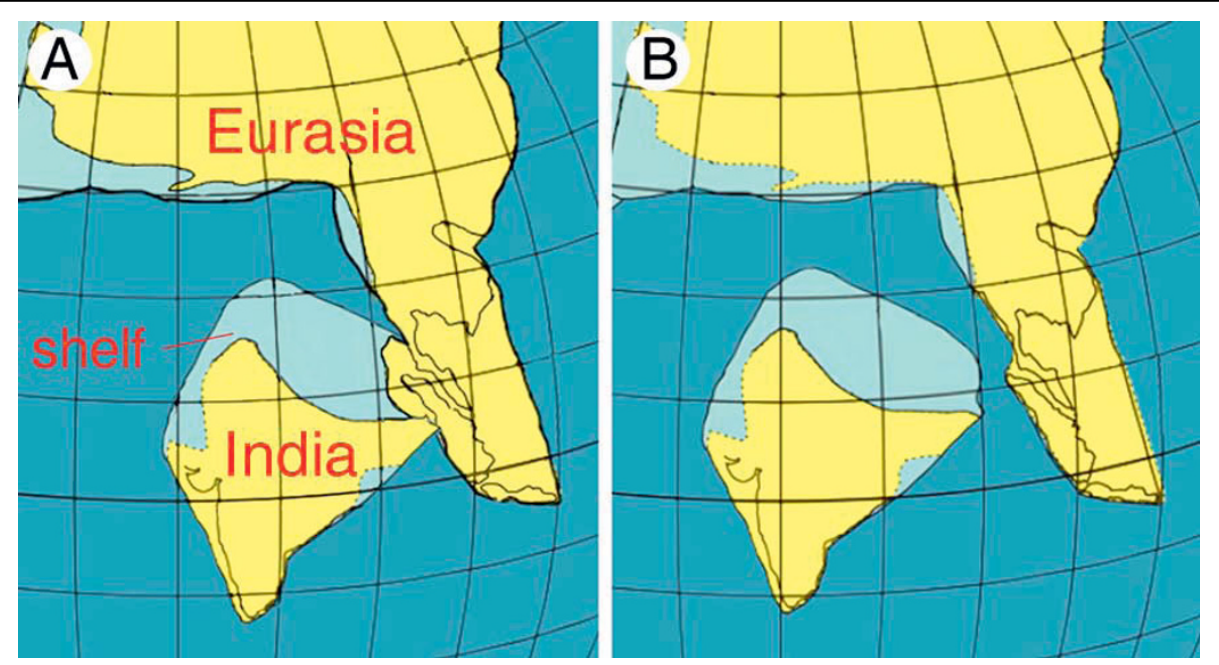

Figure 1 Eocene position of India. Relative position of the Indian and Southeast Asian continental plates during the Middle Eocene (45 Ma) according to Ali and Aitchison [17], with the position of Southeast Asia based on Hall [68], and the distribution of land and sea after Smith et al. [69]. A: based on the motion path of the Indian Subcontinent of Acton [19]. B: based on the motion path of Schettino and Scotese [18].

Freshwater crabs are considered to be good indicators of zoogeographic patterns [20]. Their ontogeny is completely independent from the marine realm, and they are thought to be drainage basin specific [21,22]. Although freshwater crabs can to some extent be saltwater tolerant under laboratory conditions [23] and may incidently have surmounted shorter marine passages by rafting [24], there is no evidence for transoceanic longdistance dispersal of freshwater crabs $[25,26]$.

The palaeotropic freshwater crab family Gecarcinucidae occurs from the Indian Subcontinent to Australia, including tropical East Asia, the Indonesian and Philippine archipelagos, the Moluccas and New Guinea [9,24]. This distribution pattern makes the Gecarcinucidae a well suited model taxon to estimate timing, direction, and possible mechanisms of faunal exchange between Southeast Asia and India during the Cenozoic.

We construct a robust molecular phylogeny of the Gecarcinucidae, provide molecular clock estimates and use these data to reconstruct ancestral ranges. Specifically, we test the fit of the respective biological data to the recently developed geological models of the IndianEurasian collision.

\section{Results}

0.1 Phylogenetic analyses and molecular clock estimates The inferred phylogenetic topology of the Gecarcinucidae is congruent in all deeper splits to a previously published phylogeny [24]. Also our Maximum Likelihood and Bayesian analyses do not conflict at the basal splits within the Gecarcinucidae. Within the subfamily Parathelphusinae our analyses retrieve the lineages identified by Klaus et al. [24], although the relationship between these lineages have low support and differ between both of our phylogenetic approaches. The Maximum Likelihood analysis supports the sister group relationship of the genus Parathelphusa with the Malesian-Australian group (in line with Klaus et al. [24]). Monophyletic and well supported are two subfamilies, the Liotelphusinae and the Parathelphusinae, while the third subfamily Gecarcinucinae is paraphyletic (Fig. 2).

The time estimate for the root of the Gecarcinucidae ranges from the Oligocene to the Cretaceous with a 95\% highest posterior density credibility interval (HPD) of 66.51-29.23 Ma. For biogeographic inference of the early evolution of the Gecarcinucidae, two nodes are of major importance: the most recent common ancestor (MRCA) of the Liotelphusinae (95\% HPD 46.63-16.85 $\mathrm{Ma}$ ) and the MRCA of the Parathelphusinae (95\% HPD 49.78-22.42 Ma), as at these nodes Indian and Southeast Asian species split. The divergence time estimation for both nodes shows a large $95 \%$ credibility interval. Therefore, we tested different temporal models that assume divergence before, during or after the final Indian-Eurasian collision around 35 Ma. A Middle Eocene origin for the MRCA of both Parathelphusinae and Liotelphusinae is strongly supported, thus most likely predating the final Indian-Eurasian collision (Table 1).

\subsection{Origin of the Gecarcinucidae and their subfamilies}

The reconstruction of the ancestral range of the Gecarcinucidae according to the Bayesian inference of ancestral character states (BayesTraits) remains equivocal. However, none of the present ancestral area reconstructions of the BayesTraits analysis has support over alternative reconstructions $\left(\log _{10}\right.$ Bayes factor $\left.<0.48\right)$. This 


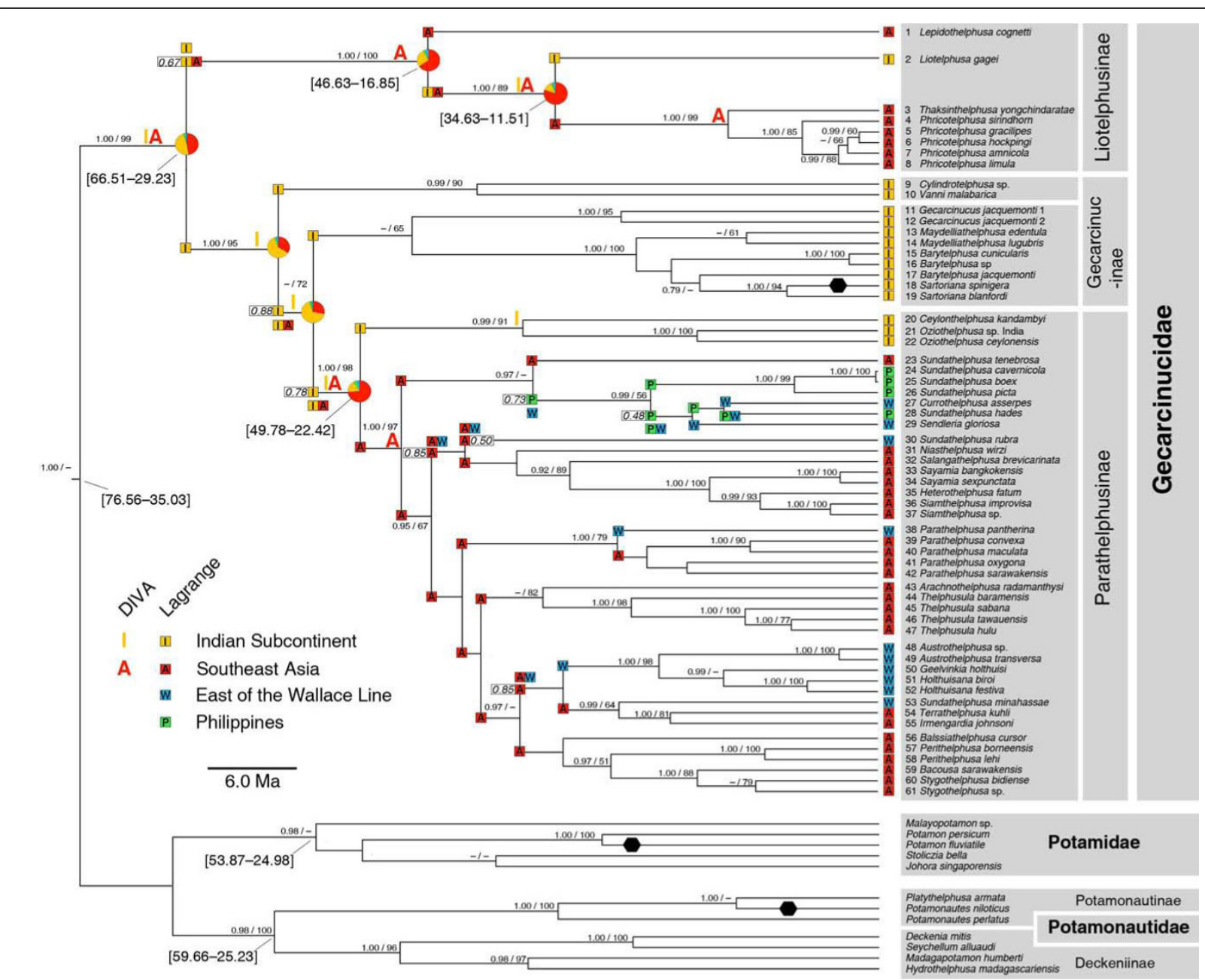

Figure 2 Phylogeny of the Gecarcinucidae. Maximum clade credibility tree of the Gecarcinucidae based on Bayesian inference of $16 \mathrm{~S}$ rDNA and histone $\mathrm{H} 3$ sequences. At nodes both the posterior probabilities (>0.90) of the Bayesian analysis and the bootstrap values (> 50) of the maximum likelihood analysis are given. Hexagons indicate the three fossil calibration points (see text), time estimates in square brackets represent the $95 \%$ confidence interval. Range inheritance as reconstructed by Lagrange is visualized by letters in colored squares, in the case of alternative reconstructions within two log-likelihood units the relative probability of the better reconstruction is added in a square box. Ancestral area reconstruction by BayesTraits is represented by pie charts with the ranges color-coded as for the Lagrange analysis.

Table 1 Testing of temporal models

\begin{tabular}{|c|c|c|c|c|c|c|c|c|}
\hline & In [post. prob.] $\pm \mathrm{SE}$ & $\begin{array}{l}\text { Para } 45 \\
\text { Liot } 45\end{array}$ & $\begin{array}{l}\text { Para } 35 \\
\text { Liot } 35\end{array}$ & $\begin{array}{l}\text { Para } 25 \\
\text { Liot } 25\end{array}$ & $\begin{array}{l}\text { Para } 45 \\
\text { Liot } 35\end{array}$ & $\begin{array}{l}\text { Para } 35 \\
\text { Liot } 45\end{array}$ & $\begin{array}{l}\text { Para } 35 \\
\text { Liot } 25\end{array}$ & $\begin{array}{l}\text { Para } 25 \\
\text { Liot } 25\end{array}$ \\
\hline Para 45 Liot 45 & $-14285.01 \pm 0.19$ & - & $0.95^{*}$ & $1.73^{* * *}$ & $0.66^{*}$ & $1.24^{* *}$ & $2.74^{* * *}$ & $1.34^{* *}$ \\
\hline Para 35 Liot 35 & $-14287.19 \pm 0.15$ & $-0,95$ & - & $0.78^{*}$ & $0.78^{*}$ & 0.29 & $1.80^{* * *}$ & 0.39 \\
\hline Para 25 Liot 25 & $-14288.99 \pm 0.17$ & -1.73 & -0.78 & - & -1.06 & -0.49 & $1.02^{* *}$ & -0.39 \\
\hline Para 45 Liot 35 & $-14286.54 \pm 0.16$ & -0.66 & -0.78 & $1.06^{* *}$ & - & $0.58^{*}$ & $2.08^{* * *}$ & $0.67^{*}$ \\
\hline Para 35 Liot 45 & $-14287.86 \pm 0.17$ & -1.24 & -0.29 & $0.49^{*}$ & -0.58 & - & $1.51^{* * *}$ & 0.10 \\
\hline Para 35 Liot 25 & $-14291.33 \pm 0.15$ & -2.74 & -1.80 & -1.02 & -2.08 & -1.51 & - & -1.41 \\
\hline Para 25 Liot 35 & $-14288.09 \pm 0.17$ & -1.34 & -0.39 & 0.39 & -0.67 & -0.10 & $1.41^{* *}$ & - \\
\hline
\end{tabular}

Testing of the temporal models with different time constraints in million years for the most recent common ancestor (MRCA) for the subfamilies

Parathelphusinae (Para) and Liotelphusinae (Liot). The first three models (first row) constrain the age of both MRCAs before, during and after the assumed final collision of India and Eurasia; the next four models assume different ages for the MRCA of Parathelphusinae and Liotelphusinae, i.e., either before or during collision of plates, or during and after this event. The natural logarithm of the models posterior probabilities and its standard error, and the common logarithm of the Bayes factor between models are given. Models in the left column are tested against the models in the first row (* substantial, ${ }^{* *}$ strong, ${ }^{* *}$ very strong support for one model over another). The first model, constraining the MRCA of both subfamilies into the Middle Eocene (45 Ma), i.e., before the final IndianEurasian collision, is superior to all other models. 
points out the necessity to test the significance of the favoured reconstruction when using this method for biogeographic purposes. Also dispersal-vicariance analysis (DIVA) does not assign the root of the Gecarcinucidae unequivocally to one area, but assumes a widespread range comprising both India and Southeast Asia.

Therefore, we also applied a likelihood approach to geographic range evolution based on dispersal, extinction and cladogenesis (DEC-model) to investigate if dispersal from India or from Southeast Asia can better explain the present range patterns. Of the three different dispersal-models calculated (Table 2), the Akaike information criterion (AIC) and Akaike weight support the $\mathrm{H}_{I \rightarrow A}$-model (allowing only dispersal from India to Asia) with a dispersal rate of $3.90 \times 10^{-3}$ and an extinction rate of $3.19 \times 10^{-4}$. Thus, dispersal from India to Southeast Asia gives the best explanation of the present data. The resulting reconstruction is shown in Fig. 2.

The Indian Subcontinent consistently emerges in all three biogeographic methods as the most likely ancestral area of the MRCA of the subfamilies Gecarcinucinae and Parathelphusinae. The Indian range is retained throughout the paraphyletic Gecarcinucinae and passed over to the Parathelphusinae, with the latter reaching Southeast Asia only once. Within this parathelphusine Southeast Asian clade a complex pattern of range evolution is reconstructed, with several transitions of the Wallace Line.

For the MRCA of the Liotelphusinae the ancestral range with the best likelihood value (according to the DEC-model) comprises both Indian and Southeast Asian areas (relative probability: 0.67 ). The Indian area is lost in the ancestor of Lepidothelphusa cognetti, whereas the Indian-Southeast Asian area was retained in the Liotelphusinae until the divergence of the genus Liotelphusa (95\% HPD 10.79-34.30 Ma). In contrast, DIVA reconstructs an Asian MRCA and secondary dispersal to India followed by vicariance.

\section{Discussion}

In agreement with previous results [9,27], the present data reject an early Gondwana distribution for the

Table 2 Testing of dispersal models

\begin{tabular}{lccc}
\hline Model & log likelihood & AIC & w \\
\hline $\mathrm{H}_{1 \rightarrow A}$ & -48.88 & 111.76 & 0.975 \\
$\mathrm{H}_{A \rightarrow 1}$ & -50.51 & 115.20 & 0.019 \\
$\mathrm{H}_{0}$ & -50.09 & 116.18 & 0.006 \\
\hline
\end{tabular}

Different dispersal models for the Gecarcinucidae that were tested in Lagrange to investigate the direction of faunal exchange between India and Southeast Asia. Given are the global maximum likelihood at the root node, the AIC, and the Akaike weight $(w)$ of the respective dispersal models. The $\mathrm{H}_{0}$ model is without any dispersal constraint, $\mathrm{H}_{I \rightarrow A}$ only allows dispersal from India to Southeast Asia, $\mathrm{H}_{A \rightarrow 1}$ only from Southeast Asia to India.
Gecarcinucidae, both concerning tree topology and time estimates. The Gondwana hypothesis for the Old World freshwater crabs does not hold against the freshwater crab fossil record (being not older than Oligocene/Miocene $[28,29])$, and is not in accordance with divergence time estimates [27] and phylogenetic reconstructions that do not reflect the break up of Eastern Gondwana $[9,24,27]$. Moreover, the initial separation of western (South America and Africa) and eastern Gondwana predates the first fossils of heterotreme marine brachyurans by approximately 50 million years.

The hypothesis of an African origin of the Gecarcinucidae can not be validated with the present data. The presumed dispersal to the Indian Subcontinent via Madagascar and the Seychelles Bank during Oligocene low sea level [9] can be rejected as the Gecarcinucidae do not nest within a paraphyletic African Potamonautidae; in contrast, the freshwater crabs of Madagascar and the Seychelles are monophyletic with the Potamonautidae. Also the estimated divergence times of the most basal splits within the Gecarcinucidae are likely to predate the Oligocene. Nevertheless, the age of separation between East African Deckenia mitis and Seychellum alluaudi from the Seychelles (95\% HPD 26.88-8.08 Ma) and the age of the deepest split within the potamonautid subfamily Deckeniinae (95\% HPD 48.54-19.29 Ma) do not conflict with the hypothesis of these Oligocene stepping stones. These could have enabled independent colonization of Madagascar and the Seychelles from Africa, as it was already proposed for amphibians and cichlid fishes [30,31], and is additionally supported by the reconstruction of Paleogene ocean currents [32]. The age of the root of the present phylogeny, and the estimated age of the Gecarcinucidae fit very well into the period of intensive brachyuran radiation, i.e., Upper Cretaceous to Early Eocene, that is apparent from the fossil record [33]. We hypothesize that during this time span the marine ancestor of the Old World freshwater crabs might have invaded the limnic habitat from the ancient Tethys Ocean. According to our biogeographic reconstruction, at least for the clade [Gecarcinucinae + Parathelphusinae], this transition occurred most likely at the shores of the Indian Subcontinent.

The results of the temporal model testing indicate that the separation of Indian and Southeast Asian species within the subfamily Parathelphusinae more likely occurred in the Middle Eocene than in the Oligocene, and according to the biogeographic reconstructions, the Indian subcontinent was by far more likely the area of origin for both Gecarcinucinae and Parathelphusinae than Southeast Asia. Provided that the final collision of India and the Tibet-part of Eurasia took place in the Late Eocene [16], we must either assume that gecarcinucid freshwater crabs surmounted a marine barrier to 
reach Southeast Asia, or that a land connection between India and Southeast Asia existed. As transoceanic long distance dispersal of freshwater crabs appears highly unlikely $[25,26]$, we conclude that India and Southeast Asia were at least very close. An early to Middle Eocene exchange of freshwater organisms is best explained by the Indian motion path of Acton $[17,19]$ which implies direct contact of plates and probably would allow terrestrial connections (Fig. 1A). In contrast, the position of the Indian Subcontinent based on Schettino and Scotese $[17,18]$ hypothesizes an open marine strait of about 500 $\mathrm{km}$ between the Indian plate and Eurasia (Fig. 1B). In fact, the exact position of western Southeast Asia during the Eocene, decisive for the present considerations, is not definitively solved and could be placed slightly eastward (J.R. Ali, pers. comm.). As in the Parathelphusinae, a Middle Eocene age for the MRCA of the Liotelphusinae is the preferred model, also predating the IndianEurasian collision. According to the DEC-model of range evolution the MRCA inhabited both Indian and Southeast Asian areas, while DIVA and the BayesTraits analysis favours a Southeast Asian origin (with the reservation that the latter is not superior to alternative reconstructions, see above). Several scenarios could explain this pattern: The liotelphusine ancestor could have had a widespread range comprising India and Southeast Asia during the Middle Eocene, as reconstructed in Lagrange. This would fit to the geological model that assumes contiguity of the Indian plate and Southeast Asia during that time. Alternatively, early diverging Indian representatives are not sampled in the present data set or could have gone extinct, raising the possibility that the ancestor of the genus Liotelphusa dispersed back to the Indian Subcontinent after the final Indian-Asian collision. Also, an independent colonization of the freshwater habitat can not be excluded with certainty. To solve the history of this subfamily with confidence, a larger sampling of the enigmatic Indian liotelphusine species will be necessary. Eocene faunal exchange between India and Southeast Asia could not only be facilitated by the paleogeographic proximity of the Indian Subcontinent and Southeast Asia, but also favored by equal climatic conditions. As indicated by coal deposits, both areas most probably have been dominated by closed-canopy megathermal rain forests during the Early Eocene, and displayed an everwet tropical climate $[8,34]$. This Indian-Southeast Asian moist corridor was already assumed to enable dispersal of Indian floral elements into Southeast Asia, corroborated by palynological evidence $[8,34,35]$.

Several Asian faunal or floral elements are claimed to be Gondwana relics, entering Asia via the northwards drifting Indian Subcontinent, i.e., the "out-of-India' scenario $[2,4,36]$. These comprise ranoid and hyloid frogs
[37,38], gymnophionans [39,40], agamid lizards [41], cichlids [42], aplocheiloid fishes [43], the Asian arowana [44], Crypteroniaceae [45] and Dipterocarpaceae [46,47]. In contrast, we present here for the first time evidence that the Gecarcinucidae, a taxon that is definitely not a Gondwana element, originated on the Indian Subcontinent, at least with the subfamily Gecarcinucidae, and dispersed into Southeast Asia during the Middle Eocene.

The early range evolution of gecarcinucid freshwater crabs exemplifies that the recently developed geological models of the Indian-Eurasian convergence are generally in accordance with biogeography [17]. Very likely this direct Eocene biotic exchange between India and Southeast Asia, possibly in both directions, accounts for the distribution patterns of a large set of organisms and probably contributed profoundly to the vast biodiversity of present South and Southeast Asia.

\section{Conclusions}

The Asian freshwater crab family Gecarcinucidae most probably originated on the Indian Subcontinent and dispersed secondarily into Southeast Asia. Within the subfamilies Gecarcinucinae and Liotelphusinae Indian and Southeast Asian species split in the Middle Eocene, before the final Indian-Eurasian collision. We postulate that the Indian plate and Southeast Asia were close enough for exchange of freshwater organisms during that period. Our data support geological models that assume the Indian plate having tracked along Southeast Asia during its move northwards.

\section{Methods}

\subsection{Phylogenetic analysis and molecular dating}

Gene sequences of the nuclear encoded histone $\mathrm{H} 3$ gene and the partial mitochondrial $16 \mathrm{~S}$ rDNA were retrieved from Genbank and originated from previous studies on the phylogeny of the Gecarcinucidae (AM234635, AM234637, AM234640, AM234641, AM234651, AM234653, AM292919[9]), (FM180114-FM180181, FM178885-FM178951[24]); and the African Potamonautidae (AY042249[21]), (AY803554, AY803710, AY803690, AY919081, AY919086-AY919088, AY919126, AY919129, AY919132, AY919135[27]).

Our study includes 57 gecarcinucid species of 31 genera. These genera (55\% of the gecarcinucid genus-level diversity) cover $60 \%$ of the currently recognized gecarcinucid species. As a sub-sample of the mitochondrial data given by Klaus et al. [24], the present study includes representatives of all gecarcinucid clades covering their whole range (Fig. 3). Only East Asian species are not included. However, these are closely related with the Southeast Asian genera Sayamia and Siamthelphusa that are included here [24]. 


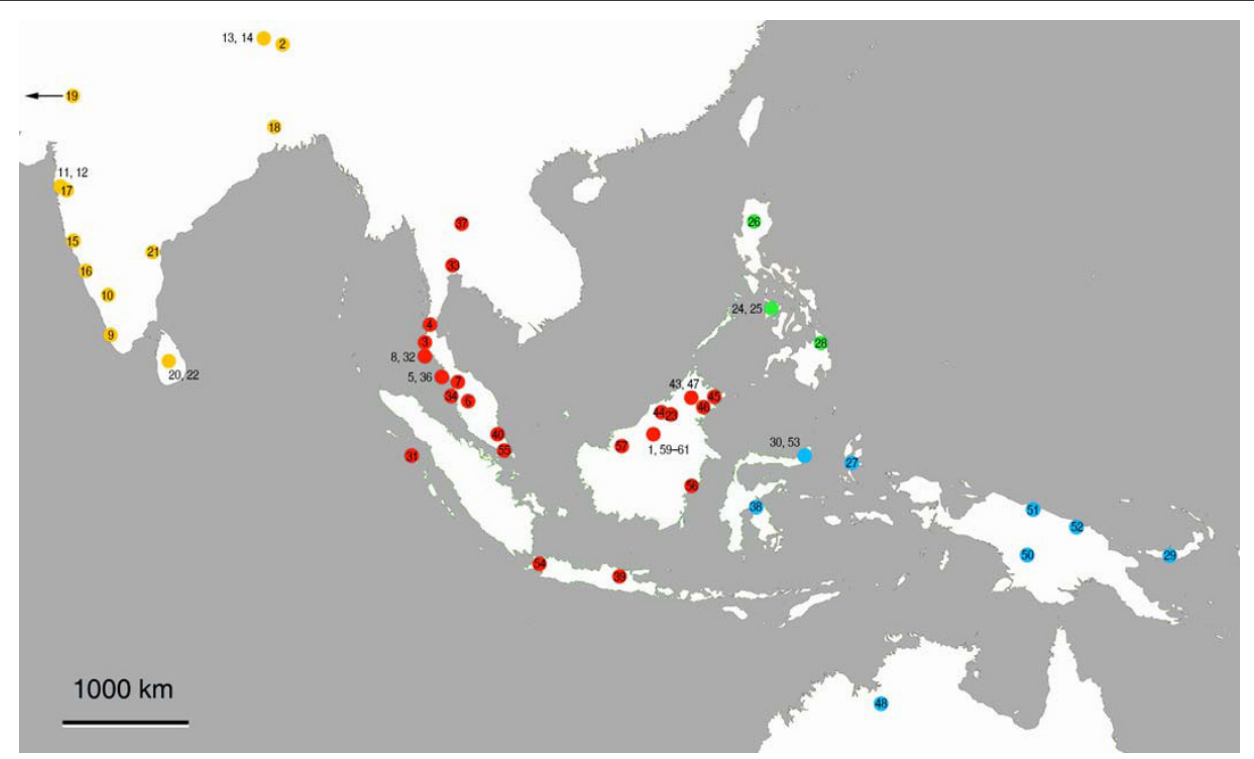

Figure 3 Sampling of gecarcinucid species. Map showing the sampling sites of the here included specimens, coloured according to the area encoding of the biogeographic analyses (yellow: India; red: Southeast Asia; green: Philippines; blue: Wallacea, New Guinea, Australia). Numbers correspond to the numbering of specimens in Fig. 2. For five specimens, originating from older collections or from the aquarium trade, only approximate locations are known, and thus are not shown here.

As outgroups we included species of the other two Old World freshwater crab families, the Eurasian-North African Potamidae and the African-Madagascan Potamonautidae. Sequences were separated in two partitions, one for the $\mathrm{H} 3$ gene (318 bp) and one for the $16 \mathrm{~S}$ rDNA (558 bp), resulting in a total sequence length of $875 \mathrm{bp}$. Alignment was done with ClustalW [48] as implemented in the software BioEdit 7.0.9.0 [49] and adjusted manually.

A maximum likelihood analysis was conducted in the software RaxML 7.0.3 [50] with the alignment partitioned for the $16 \mathrm{~S}$ rDNA gene and all three codon positions of the $\mathrm{H} 3$ gene. A GTR+I+gamma model of sequence evolution was used for the final maximum likelihood search, as suggested by the AIC in jModelTest 0.1.1 [51], while for rapid bootstrapping $\left(10^{3}\right.$ replicates) CAT approximation of rate heterogeneity is implemented in RaxML [52]. For Bayesian phylogenetic analysis and estimation of divergence times both partitions were unlinked and analysed in the software BEAST 1.5.2 [53]. After a preliminary series of test runs, the following models showed to fit best to the data: a relaxed, uncorrelated lognormal molecular clock model [54], a Yule tree prior, and a GTR $+\mathrm{I}+$ gamma model of sequence evolution. We ran the Markov chain for $10^{8}$ generations, sampling $10^{6}$ trees and discarding the first $10^{5}$ as burn-in. Convergence of the Markov chain was investigated with Tracer 1.5 [55].

To estimate divergence times we conducted two Bayesian analyses under the above conditions, one with fossil calibration points and one with a discrete rate of evolution for the $16 \mathrm{~S}$ rDNA. We used three fossil calibration points: the oldest known potamid Potamon quenstedti found in South Germany, that we assume to be closer related to the Mediterranean Potamon fluviatile than to the Near East Potamon persicum (node P. fluviatile - P. persicum; c. $16.5 \mathrm{Ma}$ [29]), a fossil of Potamonautes that was assigned to P. niloticus (node P. niloticus - Platythelphusa armata; $6 \mathrm{Ma}$ [56]) and a claw fragment from the Siwalik beds in northern India related to the genus Sartoriana [29]. As the fossil site is situated within the range of extant S. spinigera, and far from $S$. blanfordi occurring in Pakistan (Balochistan) and Afghanistan, we assume a closer relationship with S. spinigera (node S. spinigera - S. blanfordi; Gecarcinucidae, 2.5 Ma [29]). To incorporate temporal uncertainty and expecting the MRCA at the respective nodes to predate the fossils, we assumed a gamma-distribution for the calibration points with the respective age as lower cut-off value and shape parameters of 4.0, 2.0 and 3.0 respectively. These different values for the shape parameter reflect different degrees of uncertainty of the exact age and taxonomic assignment of the fossils. Although the values have to be chosen arbitrarily, this approach is considered to be much more reliable than assuming a uniform or normal prior probability distribution for the nodes' ages [57]. The default value (1.0) for the scale factor was used.

We compared the results with the second analysis using a discretized relaxed molecular clock model 
(uncorrelated lognormal) with a rate of evolution for the $16 \mathrm{~S}$ rDNA partition of $0.88 \%$ per $\mathrm{Ma}(10 \% \mathrm{SD})$. This rate was calibrated for Jamaican sesarmids based on the closure of the Isthmus of Panama [58]. We calculated the Bayes factor between the calibrated and the discretized molecular clock model. The Bayes factor is the ratio of the marginal likelihoods between two hypotheses, whereby the marginal likelihoods are here estimated in Tracer. A common logarithm of the Bayes factor $\left(\log _{10} \mathrm{BF}\right)$ larger than 0.48 indicates substantial, over 1.00 strong and above 1.48 very strong support for the respective hypothesis [59]. The comparison of the two hypotheses strongly supports the calibrated model of sequence evolution ( $\log _{10}$ BF 1.69), thus giving an independent confirmation of the adequateness of the used fossil calibration points. The sesarmid rate of $16 \mathrm{~S}$ rDNA evolution ( $0.88 \%$ per Ma) nevertheless falls within the $95 \%$ HPD credibility interval of the $16 \mathrm{~S}$ rDNA rate of the calibrated model $(0.64 \%-1.42 \%$ per Ma; mean value $1.02 \%$ per Ma). The $95 \%$ HPD of the rate of histone $\mathrm{H} 3$ is $0.12-0.26 \%$ per Ma with a mean of $0.19 \%$.

\subsection{Biogeographic analyses}

To reconstruct ancestral ranges the maximum clade credibility tree inferred by the fossil calibrated model of Bayesian inference was used as phylogenetic input for DIVA and the DEC-model. The Bayesian approach was conducted with $10^{3}$ post-burn-in trees to account for uncertainty in phylogenetic reconstruction. The gecarcinucid species were assigned to one of four discrete geographic areas: (a) the Indian Subcontinent, (b) Southeast Asia, including the Larger Sunda Islands that are situated on the continental shelf, (c) the Philippines, and (d) the gecarcinucid range east of the Wallace Line (Figs. 2 and 3). We did not take into account the distribution data of the outgroups, the potamoid families Potamidae and Potamonautidae. We have a fundamental reservation against inclusion of these to infer gecarcinucid biogeography. As long as the marine relatives of the Potamoidea remain unknown we can not exclude independent colonization of the limnic habitat by each potamoid family and consequent paraphyly of the Potamoidea. Thus we removed for the subsequent biogeographic analyses the outgroup taxa from the maximum clade credibility tree in Mesquite 2.72 [60].

Dispersal-vicariance analysis as implemented in the software DIVA [61] was conducted with maximally $10^{3}$ alternative reconstructions kept at each node and the maximum number of ancestral areas left unconstrained. We are aware of the pitfalls and limitations of eventbased biogeographic methods and consider this analysis as explorative $[62,63]$. We further analysed the data with a Bayesian approach to character evolution in BayesTraits multistate [64]. We let the analysis run for $5 \times 10^{7}$ generations, sampling $5 \times 10^{4}$ generations and discarding the first $5 \times 10^{3}$ samples as burn-in. To specify the range of values used to seed the prior distribution, we applied an exponential hyperprior with the mean from 0 to 80 and a rate deviation value of 0.1 , resulting in a mean acceptance rate of $33.4 \%(\mathrm{SD}=8.6)$. We examined at each node if there is support for one area over another: we constrained the ancestral state of the node to one area and compared the harmonic means (an estimator of marginal likelihoods) between runs under different constraints by calculating the Bayes factor between them. As harmonic means can be unstable we repeated each run five times. To test for the direction of gecarcinucid dispersal we applied a parametric DEC approach $[65,66]$ as implemented in the software Lagrange vers. 20091004 [67]. We calculated three models of gecarcinucid range evolution: an unconstrained hypothesis $\left(\mathrm{H}_{0}\right)$, a model with only dispersal from India to Asia enabled $\left(\mathrm{H}_{I \rightarrow A}\right)$, and a third model allowing only dispersal from Asia to India $\left(\mathrm{H}_{A \rightarrow I}\right)$. We compared the resulting global maximum likelihoods at the root node and the AIC and Akaike weight between models (Table 2). For all three analyses the root age was set to the mean root age (47.23 $\mathrm{Ma}$ ), adjacency of India with the Philippine range and the area East of the Wallace Line was restricted, and the rate parameters for dispersal and extinction were estimated by Lagrange.

\subsection{Timing of the Indian-Southeast Asian faunal exchange} To approximate the timing of faunal exchange between India and Southeast, and to investigate if Indian and Southeast Asian species split before, during or after the final collision of India and Eurasia, we applied a model testing approach [59]. We set different time constraints for the basal nodes of the subfamilies Liotelphusinae and Parathelphusinae (where Indian and Southeast Asian species separate) and tested several hypotheses against each other: an Oligocene (25 Ma), Late Eocene $(35 \mathrm{Ma})$ and Middle Eocene (45 Ma) age of the liotelphusine and parathelphusine MRCA. In addition, we calculated four models with the MRCAs of both subfamilies constrained to different ages, addressing the possibility that the two splits were not contemporaneous: before and during continental collision ( 45 and $35 \mathrm{Ma}$ ) and during and after this event ( 35 and $25 \mathrm{Ma}$ ). Not all theoretically possible combinations of time constraints could be calculated, as the initial tree likelihood in the Bayesian analyses dropped to zero (indicating that the respective prior model assumptions strongly contradict the data). We assumed a standard deviation of $20 \%$ to account for general temporal uncertainty. These time constraints $(45,35$ and $25 \mathrm{Ma})$ fall within the 95\% HPD credibility interval of the nodes' age estimates of the unconstrained analysis, and correspond to the time 
points for which paleogeographical reconstructions are given by Ali and Aitchison [17]. The constrained Bayesian analyses were conducted as described previously applying the calibrated relaxed molecular clock model. To evaluate the different hypotheses we calculated the Bayes factor between them in Tracer (Table 1).

\section{Acknowledgements}

We express our sincere thanks to Richard Ree for giving kind advice on Lagrange, Jason Ali for information on the geological models, and Kai Schmale and Michael Klaus for providing computational power. Special thanks goes to Martin Plath and Astrid Klingen for discussion and improvement of our manuscript. We also thank three anonymous reviewers for their constructive suggestions. MP was supported by the research funding programme "LOEWE - Landes-Offensive zur Entwicklung Wissenschaftlich-ökonomischer Exzellenz" of Hessen's Ministry of Higher Education, Research, and the Arts.

\section{Author details}

'Department of Ecology and Evolution, Goethe University, Frankfurt am Main, Germany. ${ }^{2}$ Biologie 1, University of Regensburg, Regensburg, Germany. ${ }^{3}$ Biodiversität und Klima Forschungszentrum, Frankfurt am Main, Germany.

\section{Authors' contributions}

SK and MP designed the analyses, SK conducted the analyses and wrote the manuscript, all authors discussed the results and commented on the manuscript.

Received: 30 April 2010 Accepted: 17 September 2010 Published: 17 September 2010

\section{References}

1. Briggs JC: The biogeographical and tectonic history of India. J Biogeogr 2003, 30:381-388.

2. Karanth KP: Out-of-India - Gondwanan origin of some tropical Asian biota. Curr Sci 2006, 90:789-792.

3. Van Bocxlaer I, Roelants K, Biju SD, Nagaraju J, Bossuyt F: Late Cretaceous vicariance in Gondwanan Amphibians. PLOS ONE 2006, 1:e74.

4. Datta-Roy A, Karanth KP: The Out-of-India hypothesis: What do molecules suggest? J Biosci 2009, 34:687-697.

5. Köhler F, Glaubrecht M: Out of Asia and into India: on the molecular phylogeny and biogeography of the endemic freshwater gastropod Paracrostoma Cossmann, 1900 (Caenogastropoda: Pachychilidae). Biol J Linn Soc 2007, 91:627-651.

6. van der Meijden A, Vences M, Hoegg S, Boistel R, Channing A, Meyer A: Nuclear gene phylogeny of narrow-mouthed toads (Family: Microhylidae) and a discussion of competing hypotheses concerning their biogeographical origins. Mol Phylogenet Evol 2007, 44:1017-1030.

7. Bocxlaer van I, Biju SD, Loader SP, Bossuyt F: Toad radiation reveals intoIndia dispersal as a source of endemism in the Western Ghats-Sri Lanka biodiversity hotspot. BMC Evolutionary Biology 2009, 9:131.

8. Morley RJ: Interplate dispersal paths for megathermal angiosperms. Perspect Plant Ecol Evol Syst 2003, 6:5-20.

9. Klaus S, Schubart CD, Brandis D: Phylogeny, biogeography and a new taxonomy for the Gecarcinucoidea Rathbun, 1904 (Decapoda: Brachyura). Org Divers Evol 2006, 6:199-217.

10. Prothero DR: Perissodactyls. In Encyclopedia of paleontology. Chicago, IL Edited by: Singer R, Fitzroy Dearborn 1999, 867-871.

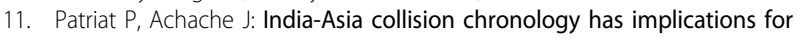
crustal shortening and driving mechanism of plates. Nature 1984 311:615-621.

12. Zhu BD, Kidd WSF, Rowley DB, Currie BS, Shaffique N: Age of initiation of the India-Asia collision in the east-central Himalaya. J Geol 2004, 113:265-285

13. Leech ML, Singh S, Jain AK, Klemperer SL: The onset of India-Asia continental collision: early, steep subduction required by the timing of UHP metamorphism in the western Himalaya. Earth Planet Sci Lett 2005, 234:83-97.
14. Abrajevitch A, Ali JR, Aitchison JC, Davis AM, Liu J, Ziabrev S: Neotethys and the India-Eurasia collision: insights from a palaeomagnetic study of the Dazhuqu ophiolite, southern Tibet. Earth Planet Sci Lett 2005, 233:87-102.

15. Ali JR, Aitchison JC: Positioning Paleogene Eurasia problem: solution for 60-50 Ma and broader tectonic implications. Earth Planet Sci Lett 2006 251:148-155.

16. Aitchison JC, Ali JR, Davis AM: When and where did India and Asia collide? J Geophys Res 2007, 112:B05423.

17. Ali JR, Aitchison JC: Gondwana to Asia: Plate tectonics, paleogeography and the biological connectivity of the Indian sub-continent from the Middle Jurassic through latest Eocene (166-35 Ma). Earth-Science Reviews 2008, 88:145-166.

18. Schettino A, Scotese CR: Apparent polar wander paths for the major continents (200 Ma to the present day): a palaeomagnetic reference frame for global plate tectonic reconstructions. Geophys J Int 2005, 163:727-759.

19. Acton GD: Apparent polar wander of India since the Cretaceous with implications for regional tectonics and true polar wander. In The Indian Subcontinent and Gondwana: a Palaeomagnetic and Rock Magnetic Perspective. Edited by: Radhakrishna T, Piper JDA. Mem Geol Soc India; 1999:44:129-175.

20. $\mathrm{Ng} \mathrm{PKL}$, Rodriguez G: Freshwater crabs as poor zoogeographical indicators: a critique of Banarescu 1990. Crustaceana 1995, 68:636-645.

21. Daniels SR, Stewart BA, Gouws G, Cunningham M, Matthee CA: Phylogenetic relationships of the southern African freshwater crab fauna (Decapoda: Potamonautidae: Potamonautes) derived from multiple data sets reveal biogeographic patterning. Mol Phylogenet Evol 2002, 25:511-523.

22. Daniels SR: Examining the genetic structure among populations of the common Cape river crab Potamonautes perlatus from river systems in South Africa reveals hydrographic boundaries. J Crust Biol 2003, 23:936-950.

23. Morris S, Van Aardt WJ: Salt and water relations, and nitrogen excretion, in the amphibious African freshwater crab Potamonautes warreni in water and air. J Exp Biol 1998, 201:883-893.

24. Klaus S, Brandis D, Ng PKL, Yeo DCJ, Schubart CD: Phylogeny and biogeography of Asian freshwater crabs of the family Gecarcinucidae (Crustacea: Brachyura: Potamoidea). In Crustacean Issuesx: Decapod Crustacean Phylogenetics. Edited by: Martin JW, Crandall KA, Felder DL. Francis 2009:509-531.

25. Shih HT, Hung HC, Schubart CD, Chen CLA, Chang HW: Intraspecific genetic diversity of the endemic freshwater crab Candidiopotamon rathbunae (Decapoda, Brachyura, Potamidae) reflects five million years of the geological history of Taiwan. J Biogeogr 2006, 33:980-989.

26. Shih HT, Fang SH, Ng PKL: Phylogeny of the freshwater crabs genus Somanniathelphusa Bott (Decapoda: Parathelphusidae) from Taiwan and the coastal regions of China, with notes on their biogeography. Invertebr Syst 2007, 21:29-37.

27. Daniels SR, Cumberlidge N, Pérez-Losada M, Marijnissen SAE, Crandall KA: Evolution of Afrotropical freshwater crab lineages obscured by morphological convergence. Mol Phylogenet Evol 2006, 40:227-235.

28. Feldmann RM, O'Connor PM, Stevens NJ, Gottfried MD, Roberts EM, Ngasala S, Rasmusson EL, Kapilima S: A new freshwater crab (Decapoda: Brachyura: Potamonautidae) from the Paleogene of Tanzania, Africa. $N$ Jb Geol Paläont Abh 2007, 244:71-78.

29. Klaus S, Gross M: Synopsis of the fossil freshwater crabs of Europe (Crustacea: Brachyura: Potamidae). N Jb Geol Paläont Abh 2010, 256:39-59.

30. Vences M, Freyhof J, Sonnenberg R, Kosuch J, Veith M: Reconciling fossils and molecules: Cenozoic divergence of cichlid fishes and the biogeography of Madagascar. J Biogeogr 2001, 28:1091-1099.

31. Vences M, Kosuch J, Glaw F, Böhme W, Veith M: Molecular phylogeny of hyperoliid treefrogs: biogeographic origin of Malagasy and Seychellean taxa and re-analysis of familial paraphyly. J Zoo Syst Evol Res 2003, 41:205-215.

32. Ali JR, Huber M: Mammalian biodiversity on Madagascar controlled by ocean currents. Nature 2010, 463:653-657.

33. Brösing A: A reconstruction of an evolutionary scenario for the Brachyura (Decapoda) in the context of the Cretaceous-Tertiary boundary. Crustaceana 2009, 81:271-287. 
34. Morley RJ: Origin and Evolution of Tropical Rain Forests Wiley, Chichester 2000.

35. Morley RJ: Palynological evidence for Tertiary plant dispersals in the SE Asia region in relation to plate tectonics and climate. In Biogeography and Geological Evolution of SE Asia. Edited by: Hall R, Holloway J. Backhuys, Leiden; 1998:177-200.

36. McKenna MCC: Sweepstakes, filters, corridors, Noah's arks, and beached Viking funeral ships in palaeography. In Implications of continental drift to the earth sciences. Edited by: Tarling DH, Runcorn SK. Academic Press, London; 1973:291-304.

37. Bossuyt F, Milinkovitch MC: Amphibians as indicators of early Tertiary outof-India dispersal of vertebrates. Science 2001, 292:93-95

38. Dutta SK, Vasudevan K, Chaitra MS, Shanker K, Aggarwal R: Jurassic frogs and the evolution of amphibian endemism in the Western Ghats. Curr Sci 2004, 86:211-216

39. Gower DJ, Kupfer A, Oommen VO, Himstedt W, Nussbaum RA, Loader SP, Presswell B, Müller H, Krishna SB, Boistel R, Wilkinson M: A molecular phylogeny of ichthyopiid caecilians (Amphibia: Gymnophiona, Ichthyophiidae): out of India or out of South East Asia? Proc $R$ Soc Lond B 2002, 269:1563-1569.

40. Wilkinson M, Sheps JA, Oommen OV, Cohen L: Phylogenetic relationships of Indian caecilians (Amphibia: Gymnophiona) inferred from mitochondrial rRNA gene sequences. Mol Phylogenet Evol 2002, 23:401-407.

41. Macey JR, Schulte JA II, Larson A, Ananjeva NB, Wang Y, Pethiyagoda R, Rastegar-Pouyani N, Papenfuss TJ: Evaluating trans-tethys migration: an example using acrodont lizard phylogenetics. Syst Biol 2000, 49:233-256.

42. Sparks JS: Molecular phylogeny and biogeography of the Malagasy and South Asian cichlids (Teleostei: Perciformis: Cichlidae). Mol Phylogenet Evol 2003, 30:599-614.

43. Murphy WJ, Collier GE: A molecular phylogeny for aplocheiloid fishes (Atherinomorpha, Cypridontiformes): the role of vicariance and the origins of annualism. Mol Biol Evol 1997, 14:790-799.

44. Kumazawa Y, Nishida M: Molecular phylogeny of Osteoglossoids:A new model for Gondwanian origin and plate tectonic transportation of Asian arowana. Mol Biol Evol 2000, 17:1869-1878.

45. Conti E, Eriksson T, Schönenberger KJ, Sytsma KJ, Baum DA: Early Tertiary out-of-India dispersal of Crypteroniaceae: evidence from phylogeny and molecular dating. Evolution 2002, 56:1931-1942.

46. Dayanandan S, Aston PS, Williams SM, Primack RB: Phylogeny of the tropical tree family Dipterocarpaceae based on nucleotide sequences of the chloroplast rbcL gene. Am J Bot 1999, 86:1182-1190

47. Ducousso M, Bena G, Bourgeois C, Buyck B, Eyssartier G, Vincelette M, Rabevohitra R, Randrihasipara L, Dreyfus B, Prin Y: The last common ancestor of Sarcolaenaceae and Asian dipterocarp trees was ectomycorrhizal before the India-Madagascar separation, about 88 million years ago. Mol Ecol 2004, 13:231-236.

48. Thompson JD, Higgins DG, Gibson TJ: CLUSTAL W: improving the sensitivity of progressive multiple sequence alignment through sequence weighting, position-specific gap penalties and weight matrix choice. Nucleic Acids Res 1994, 22:4673-4680.

49. Hall TA: BioEdit: a user-friendly biological sequence alignment editor and analysis program for Windows 95/98/NT. Nucleic Acids Symp Ser 1999, 41:95-98.

50. Stamatakis A: RAxML-VI-HPC: Maximum likelihood-based phylogenetic analyses with thousands of taxa and mixed models. Bioinformatics 2006 22:2688-2690

51. Posada D: jModelTest: Phylogenetic Model Averaging. Mol Biol Evol 2008, 25:1253-1256.

52. Stamatakis A: Phylogenetic models of rate heterogeneity: A high performance computing perspective. Proc of IPDPS2006, Rhodos, Greece 2006

53. Drummond AJ, Rambaut A: BEAST: Bayesian evolutionary analysis by sampling trees. BMC Evolutionary Biology 2007, 7:214.

54. Drummond AJ, Ho SYW, Phillips MJ, Rambaut A: Relaxed phylogenetics and dating with confidence. PLOS Biology 2006, 4:e88.

55. Rambaut A, Drummond AJ: Tracer v1.4. 2007 [http://beast.bio.ed.ac.uk/ Tracer].

56. Carriol RP, Secrétan B: Présence dans la basin du Lac Albert (Ouganda), des le Miocéne supérieur, de Potamonautes (Acantothelphusa) niloticus (Crustacea, Brachyura). Comp Rend Acad Sciences, Paris 1992, 314:411-417.
57. Ho SYW: Calibrating molecular estimates of substitution rates and divergence times in birds. J Avian Biol 2007, 38:409-414.

58. Schubart CD, Diesel $R$, Hedges SB: Rapid evolution to terrestrial life in Jamaican crabs. Nature 1998, 393:363-365.

59. Pfenninger M, Vela E, Jesse R, Arantzazu Elejalde M, Liberto F, Magnin F, Martínez-Orti A: Temporal speciation pattern in the western Mediterranean genus Tudorella P. Fischer, 1885 (Gastropoda Pomatiidae) supports the Tyrrhenian vicariance hypothesis. $\mathrm{Mol}$ Phylogenet Evol 2010, 54:427-436.

60. Maddison WP, Maddison DR: Mesquite: a modular system for evolutionary analysis. Version 2.71. 2009 [http://mesquiteproject.org].

61. Ronquist F: Dispersal-vicariance analysis: A new approach to the quantification of historical biogeography. Syst Biol 1997, 46:195-203.

62. Kodandaramaiah $\mathrm{U}$ : Use of dispersal-vicariance analysis in biogeography a critique. J Biogeogr 2010, 37:3-11.

63. Ree HR, Sanmartín I: Prospects and challenges for parametric models in historical biogeographical inference. J Biogeogr 2009, 36:1211-1220.

64. Pagel M, Meade A, Barker D: Bayesian estimation of ancestral character states on phylogenies. Syst Biol 2004, 53:673-684.

65. Ree RH, Moore BR, Webb CO, Donoghue MJ: A likelihood framework for inferring the evolution of geographic range on phylogenetic trees. Evolution 2005, 59:2299-2311.

66. Ree HR, Smith SA: Maximum likelihood inference of geographic range evolution by dispersal, local extinction and cladogenesis. Syst Biol 2008, 57:4-14

67. Ree HR, Smith SA: Lagrange (Software for likelihood analysis of geographic range evolution), version 2. 2007 [http://lagrange.googlecode. com].

68. Hall R: Cenozoic geological and plate tectonic evolution of SE Asia and the SW Pacific: computer-based reconstructions, model and animations. J Asian Earth Sci 2002, 20:353-431.

69. Smith AG, Smith DG, Funnell BM: Atlas of Mesozoic and Cenozoic Coastlines Cambridge University Press 1994.

doi:10.1186/1471-2148-10-287

Cite this article as: Klaus et al:: When Indian crabs were not yet Asian biogeographic evidence for Eocene proximity of India and Southeast Asia. BMC Evolutionary Biology 2010 10:287.

\section{Submit your next manuscript to BioMed Central and take full advantage of:}

- Convenient online submission

- Thorough peer review

- No space constraints or color figure charges

- Immediate publication on acceptance

- Inclusion in PubMed, CAS, Scopus and Google Scholar

- Research which is freely available for redistribution
Biomed Central 